\title{
A clinical study of Bilvadi panchmool ghanvati in The management of Sthaulya w.s.r. to Obesity
}

\author{
Research Article
}

\section{Vyas Jatin $\mathbf{M}^{1^{*}}$, Pandya Shachi $\mathbf{H}^{2}$, Patel Dhananjay $\mathbf{V}^{3}$, Dave Sharadbhai $\mathrm{K}^{4}$}

1. Lecturer, Department of Kayachikitsa, J.S.Ayurved College, Nadiad.

2. Lecturer, Department of S.R.P.T., GJPIASR, New V.V.Nagar.

3. Reader, Department of Kayachikitsa, Shree Gulabkunvarba Ayurved Mahavidyalaya, Jamnagar.

4. Ex. Lecturer, Department of Kayachikitsa, Government Akhandanand Ayurved College, Ahmedabad.

\begin{abstract}
Today most of the non-communicable diseases have higher prevalence. Sthaulya (obesity or overweight) is one of them. This disorder has constituted a most important epidemic in the initial decades of the $21^{\text {st }}$ century. Taking into consideration this fact a randomized clinical study was carried out with an aim to study the clinical efficacy of "Bilvadi Panchmool Ghanvati" in the management of Sthaulya (obesity). Amongst these, 15 patients were treated with Bilvadi Panchmool Ghanvati compound in the dose of 2 gram (4 tablets of $500 \mathrm{mg}$ ) 3 times a day with Madhudak before meal. The duration of treatment was 8 weeks with follow-up for 4 weeks after the completion of treatment. Analysis of the overall effects showed that Bilvadi Panchmool Ghanvati provided marked reduction in weight, body mass index, and other signs and symptoms in patients of Sthaulya.
\end{abstract}

Keywords: Sthaulya, obesity, Bilvadi Panchmool Ghanvati.

\section{Introduction}

Sthaulya is metabolic disorder described in Ayurvedic texts thousands of years ago. The same etiopathogenesis and symptomatology present today as described in classics. Acharya Sushruta said that the last complication of Sthaulya is Panchapanchatva which means death. W.H.O. has undertaken obesity in 10 selected risks to the health in "The World Health Report - 2002".

Obesity is a chronic disease that is highly prevalent and that poses a serious risk for the development of diabetes mellitus, hypertension, cardiovascular diseases, musculoskeletal disorders especially osteoarthritis and certain forms of cancer.(1), (2).

Obesity has taken place as an epidemic problem yet still majority of people are not aware of the factors that welcome this problem and the results that are obtained after one gets into this problem. At least 2.6 million people each year die as a result of being overweight or obese.(3).

Sthaulya is considered as Santarpanjanya Vyadhi (over nutritional) (4), due to excessive accumulation of Meda (depot fat) in Body. Because of Dietary habits,

*Corresponding Author:

Vyas Jatin M

Lecturer,

Department of Kayachikitsa,

J.S.Ayurved College,

Nadiad

E-mail: vaidyajatinvyas87@gmail.com sedentary life style, stress, technology etc. it has become widespread disease with so many complaints. If we go through Ayurvedic formulations which are used in Sthaulya, Guggulu is found to be main ingredient in most of them. But it is also seen that Guggulu is not suitable to all in context to Prakriti, Desha and Kala etc. So there is necessity to find out substitute.

While describing the treatment of Sthaulya, Acharya Charaka emphasized on the use of Ruksha, Ushna and mainly Kapha Vatashamana drugs like Bilvadi Panchmool and use of Madhu Udaka for the management of Sthaulya. (5) Therefore Bilvadi Panchmool Ghanvati was selected for clinical study.

In Bilvadi Panchmool Ghanvati, there is combination of five drugs i.e. Bilva, Agnimanth, Gambhari, Patla and Shyonak.

\section{Aims and Objectives}

- To study causes of Sthaulya described in classics.

- To study the clinical efficacy of "Bilvadi Panchmool Ghanvati" in the management of Sthaulya (obesity).

\section{Materials and Methods}

A total of 17 patients of Sthaulya from O.P.D. and I.P.D. of Govt. Akhandanand Ayurvedik Hospital, as well as Govt. Maniben Ayurvedik Hospital, Ahmedabad were registered for this study. Out of this 2 Patients dropped out, and 15 patients completed the prescribed course of treatment.

\section{Plan of Study}

An open label clinical trial was conducted on 
patients, where patients were given treatment for 8 weeks with 4 months follow up. Patients were given specific instructions on diet and life style modifications. Bilvadi Panchmool Ghanvati given in 4 tablets (each tablet 500mg) thrice a day with Madhudaka. The composition of Bilvadi Panchmool Ghanvati is described below.

\begin{tabular}{|l|l|l|l|}
\hline Content & Latin name & $\begin{array}{l}\text { Part } \\
\text { used }\end{array}$ & Ratio \\
\hline Bilva & $\begin{array}{l}\text { Aegle marmelos } \\
\text { corr. }\end{array}$ & Root & 1 part \\
\hline Agnimantha & $\begin{array}{l}\text { Premna } \\
\text { mucronata roxb. }\end{array}$ & Root & 1 part \\
\hline Shyonaka & $\begin{array}{l}\text { Oroxylum indicum } \\
\text { vent. }\end{array}$ & Root & 1 part \\
\hline Patla & $\begin{array}{l}\text { Stereospermum } \\
\text { suaveolens dc. }\end{array}$ & Root & 1 part \\
\hline Gambhari & $\begin{array}{l}\text { Gmelina arborea } \\
\text { linn. }\end{array}$ & Root & 1 part \\
\hline
\end{tabular}

\section{Inclusion criteria}

- Patient having classical sign and symptoms of Sthaulya like Chala Sphika Udara, Stana, Durbalya, Atikshudha, Atitrishna, Daurgandhya, Alpavyavaya etc.

- Age: - 16-60 years.

- BMI :- $>25$ and $\leq 40$.

\section{Exclusion criteria}

- Patients having age $<16$ years and $>60$ years.

- Patients having serious cardiac, pulmonary, renal and hepatic diseases etc.

- Pregnant females and lactating women.

- Patients having history of Diabetes Mellitus, Thyroid disorders and uncontrolled Hypertension and other endocrine diseases.

- Obesity due to drugs e.g. Anticonvulsant, Betablockers, Corticosteroid.

- Patients having BMI > 40 were excluded.

\section{Investigation}

- S. Cholesterol and fasting blood sugar was carried out in all the patients before initiating the administration of trial drugs and after the completion of course of treatment. Routine investigation of blood and urine were also done to rule out other pathologies and to judge any adverse effect of the drugs.

\section{Criteria for assessment}

- Total Assessment of the Therapy was done on the basis of relief in the signs and symptoms as well as objective criteria Body weight measurement, BMI, $\mathrm{W} / \mathrm{H}$ ratio, Skin fold thickness. The efficacy of the therapy was assessed on the basis of the following subjective as well as objective criteria.

\section{Subjective criteria}

The patients were assessed twice by giving a score before and after the therapy according to the severity of the symptoms. Statistical analysis was carried out to obtain the efficacy of the therapy.

The details of the scoring pattern adopted for the main signs and symptoms in the present study were as follows.

\section{Chala Sphika Udara Stana (Visible Movement In Hip- Abdomen-Breast)}

Absence of Chalatva

Little visible movement (in the areas) after rap- $\quad 1$

Little visible movement (in the areas) even after 2

Movement (in the areas) after mild movement 3

Movement (in the areas) even after changing 4

\section{Alasya/ Utsahahani (Laziness/ Lack of Enthusiasm)}

No Alasya or Lack of Enthusiasm (doing work 0

Doing work satisfactorily with late initiation $\quad 1$

Doing work unsatisfactorily under mental pres- 2

Not starting any work on his own responsibility 3

Does not take any initiation and does not want

4

\section{Kshudra Shwasa/Ayase Shwasa (Dyspnoea On Exertion)}

No Dyspnoea even after heavy work

Dyspnoea after moderate work but relieved later and tolerable; dyspnoea By climbing upstairs of 10 steps and time taken will be more than 15 sec.

Dyspnoea after little work but relieved later and tolerable; dyspnoea by climbing upstairs of 10 steps and time taken will be more than $25 \mathrm{sec}$. Dyspnoea after little work but relieved later and not tolerable; dyspnoea

by climbing upstairs of 10 steps and time taken will be more than $35 \mathrm{sec}$.

Dyspnoea in resting condition

\section{Daurbalyata-Alpa Vyayama (Weakness)}

Can do routine exercise

Can do moderate exercise without difficulty

Can do only mild exercise

Can do mild exercise with difficulty

Cannot do even mild exercise

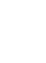

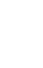

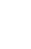

4




\section{Nidradhikya (Excess sleep)}

Normal and sound sleep for $6-8 \mathrm{hrs} . / 24 \mathrm{hrs}$. with feeling of lightness and relaxation in the body and mind

Sleep $\geq 8-9$ hrs. $/ 24$ hrs. With slight heaviness in 1 the body.

Sleep $>8-9$ hrs. $/ 24$ hrs. With slight heaviness in 2 the body.

Sleep $>10 \mathrm{hrs} . / 24 \mathrm{hrs}$. With heaviness in the body associated with Jrimbha and Tandra.

\section{Swedadhikya (Excess Sweating)}

Sweating after heavy work and fast movement or in very hot weather.

Profuse sweating after moderate work and movement.

Sweating after little work and movement.

Profuse sweating after little work and movement.

Sweating even at rest or in cold season.

\section{Daurgandhya (Body Odour)}

No odour.

Bad odour but not offensive.

Strong odour but can be lessened by use of deodorants or perfumes.

Very strong odour even after using fragrances (use of deodorants or perfumes).

\section{Atipipasa (Excess Thirst)}

Feeling of thirst ( $7-9$ times/24 hours) and relieved by drinking water.

Feeling of moderate thirst $(>9-11$ times/24 hours) and relieved by drinking water.

Feeling of excess thirst $(>11-13$ times $/ 24$

hours) not relieved by drinking water.

Feeling of sever thirst ( $>13$ times/24 hours) not relieved by drinking water.

\section{Atikshudha (Excess Hunger)}

As usual / routine

Slightly increased (1 meal extra with routine diet).

Moderately increased ( 2 meals extra with routine diet).

Markedly increased ( 3 meals extra with routine diet).

\section{Alpa Vyavaya (Less Libido)}

Unimpaired libido and sexual performance.

Decrease in libido but can perform sexual act.

Decrease in libido but can perform sexual act with difficulty.

Loss of libido and cannot perform sexual act.

\section{Anga Shaithilya (Flabbiness in the body)}

0

No flabbiness in the body.

Flabbiness in one anatomical region.

Flabbiness in more than one anatomical region 2 which does not cause distress.

Flabbiness in all over the body which causes distress to the patient.

\section{Gadgadvani ( Indistinct speech)}

Unimpaired voice.

Difficult speech which can be understood easily.

Difficult speech which can be understood with difficulty.

Difficult speech which cannot be understood.

\section{Associated Symptoms \\ Sandhi Shool (Joint pain)}

$$
\text { No pain. }
$$

Mild pain of bearable nature comes occasionally. Moderate pain, but no difficulty in moving. $\quad 2$

Slight difficulty in moving due to pain.

Much difficulty in moving the bodily parts and 4 pain is severe.

The assessment was done before starting the treatment and after the treatment i.e.; at the completion of the treatment and the improvement was assessed on the basis of percentage relief obtained and statistical evaluations.

\section{Objective Criteria:}

Weight: Reduction of weight was compared in comparison before treatment and after treatment.

\section{Body mass index (BMI):}

The body mass index (BMI) is a statistical measurement which compares a person's weight and height. The frequent use of the BMI is to assess how much an individual's body weight departs from what is normal or desirable for a person of his or her height. For a given height, BMI is proportional to weight. However, for a given weight, BMI is inversely proportional to the square of the height. The B.M.I. is the actual body weight divided by the height squared in meter $\left(\mathrm{kg} / \mathrm{m}^{2}\right)$. This index provides a satisfactory measure of obesity in people who are not hypertrophied athletes. The classification of obesity as per B.M.I. by W.H.O. Criteria is as:
- Under weight

- Normal weight

- Over weight

- Obesity (Class-I)

- Obesity (Class-II)

- Morbid Obesity (Class-III)
$-<18.5 \mathrm{~kg} / \mathrm{m}^{2}$

- $18.5-24.9 \mathrm{~kg} / \mathrm{m}^{2}$

- $25-29.9 \mathrm{~kg} / \mathrm{m}^{2}$

$-30-34.9 \mathrm{~kg} / \mathrm{m}^{2}$

- $35-39.9 \mathrm{~kg} / \mathrm{m}^{2}$ 


\section{Body Circumference Measurements:}

Circumferences of fatty parts (Neck, chest, abdomen, mid arm, mid forearm, hip, waist, mid thigh, mid calf) were recorded before and after treatment, to assess the effect of therapy.

\section{Skin Fold Thickness:}

The skin fold thickness was measured by Vernier calipers before and after treatment in fixed areas of middle portions of the biceps and triceps muscles, middle portion of the supra iliac region and the anterior surface of midthigh region and of abdominal muscle at umbilicus.

\section{Treatment protocol:}

Total 15 patients of Sthaulya were treated in the Bilvadi Panchmool Ghanvati group.

Details:

$\begin{array}{cc}\text { Drug } & \text { Bilvadi Panchmool Ghanvati } \\ \text { Dose } & \text { 4tablets (each 500mg) } 3 \text { times a } \\ \text { Total dose } & 6 \text { gm per day } \\ \text { Anupana } & \text { Madhu Udaka } \\ \text { Duration } & 8 \text { Weeks } \\ \text { Time of } & \text { Before meal }\end{array}$

The research drug was prepared by Govt. Ayurvedik Pharmacy at Rajpipala.

\section{Assessment of Overall effect of therapy:-}

The overall effect was decided on the basis of Improvement in Subjective parameters and reduction in Objective criteria i.e. Weight, BMI, Skin fold thickness and $\mathrm{W} / \mathrm{H}$ Ratio.

In this part, percentage improvement in Objective criteria i.e. Weight, BMI, Skin fold thickness and $\mathrm{W} / \mathrm{H}$ ratio were assessed and then average of all the percentage improvement was taken. Similarly for subjective parameters percentage improvement in each subjective parameter present in the patient was assessed and then average of all the percentage improvement of subjective parameters was taken.

For percentage improvement in each Objective parameter, it is calculated at maximum or upper normal limit of normal range i.e. for BMI, percentage improvement is calculated by assuming 25 (upper limit of normal range) as 0 and improved percentage derived from difference of before and after treatment assessment.

Finally to assess the total effect of the Therapies an average of Subjective and objective parameter was taken. Thus the total effect of the Therapies was marked as following:

$\begin{array}{ll}\begin{array}{l}\text { Percentage } \\ \text { Relief }\end{array} & \text { Effects } \\ 100 \% & \text { Complete remission } \\ 75-99 \% & \text { Markedly improved } \\ 50 \%-75 \% & \text { Moderately improved } \\ 25 \%-50 \% & \text { Improved } \\ 10 \%-25 \% & \text { Mildly improved } \\ 0 \%-10 \% & \text { Unchanged }\end{array}$

\section{Statistical Estimation of results}

The Wilcoxon signed-rank test is applied to the statistical data for evaluating the Subjective Criteria. Chi square test is applied to the statistical data for evaluating the difference in the effects of two therapies symptom wise.

Students Paired ' $t$ ' applied to the statistical data for evaluating the difference in the B.T. and A.T. scores of Objective parameters. Students Unpaired' $t$ ' test is applied for evaluating the difference in the effects of two therapies Objective Parameter wise.

\section{Observations}

In the present study of 17 patients of Sthaulya, maximum number of patients were in the age group of $31-45$ years $(52.94 \%)$,females $(82.35 \%)$, Hindu by religion $(70.58 \%)$, married $(76.47 \%)$, belonging to middle socioeconomic class $(64.71 \%)$, and from Sadharana Desha.(100\%). Further, in this study maximum number of patients were of Kapha Vata Prakriti (41.17\%), Tamsik Prakriti (47.06\%). 58.82\% patients of this study were vegetarian, $58.82 \%$ patients were doing only the routine work, $41.17 \%$ patients were having sedentary life, $76.47 \%$ patients were having sound sleep and $41.18 \%$ were jolly in nature.

Majority of the patients in this study, that is, $82.35 \%$ were consuming Snigdha Guna followed by 64.70\% Guru Guna Pradhana diet and $76.47 \%$ willing to Madhura Rasa, followed by $70.58 \%$ Lavana Rasa. Bhojanottara Jalapana was observed in $82.35 \%$, $64.70 \%$ were taking regular diet, Tikshnagni in $47.05 \%$, Madhyama Koshtha in $70.59 \%$.

In this study, as chief complains, Maximum i.e. $100 \%$ of the patients were found to have chief complaints of Chala Udara followed by $82.35 \%$ reporting Chala Sphika, 82.35 \% reporting Chala Stana and Ati Kshdha, $88.23 \%$ reporting Alasya/Utsahahani, 76.47 \% reporting Ayasena Shwasa /Kshudra Shwasa, $76.47 \%$ reporting Nidradhikya and Swedadhikya, 76.47 \% reporting Ati Pipasa, 82.35 \% reporting 
Vyas Jatin M et.al., A Clinical study of Bilvadi panchamool ghanvati in the management of Sthaulya (Obesity)

Daurbalya, $58.82 \%$ reporting Daurgandhya.

In objective criteria, maximum $52.94 \%$ of patients were having weight in the category of 70-80 $\mathrm{kg}$. Maximum $41.18 \%$ of the patients were having BMI in the range of $30-34.90 \mathrm{~kg} / \mathrm{m}^{2}$ (Grade 1 obesity). Maximum i.e. $33.33 \%$ of the male patients were having waist circumference more than $102 \mathrm{~cm}$ and $78.57 \%$ females were having waist circumference more than 88 $\mathrm{cm}$. Maximum i.e. $100 \%$ of the male patients were having waist to hip ratio more than 0.9 and $71.43 \%$ females were having waist to hip ratio more than 0.85 . As biochemical investigation, maximum 58.82\% patients were having S. Cholesterol $<200 \mathrm{mg} / \mathrm{dl}$.

Table: 1 Subjective criteria: chief complaints

\begin{tabular}{|l|c|l|}
\hline \multicolumn{1}{|c|}{ Chief complaints } & Number of & \% \\
\hline Chala Sphika & 14 & 82.35 \\
\hline Chala Udara & 17 & 100 \\
\hline Chala Stana & 14 & 82.35 \\
\hline Alasya /Utsahahani & 15 & 88.23 \\
\hline $\begin{array}{l}\text { Ayasena Shwasa } \\
\text { Kshudrashwasa }\end{array}$ & 13 & 76.47 \\
\hline $\begin{array}{l}\text { Daurblyata-Alpa } \\
\text { Vyayam }\end{array}$ & 14 & 82.35 \\
\hline Nidradhikya & 13 & 76.47 \\
\hline Swedadhikya & 13 & 76.47 \\
\hline Daurgandhya & 10 & 58.82 \\
\hline Ati Pipasa & 13 & 76.47 \\
\hline Ati Kshudha & 14 & 82.35 \\
\hline Alpa Vyavaya & 7 & 41.18 \\
\hline Anga Shaithilya & 1 & 52.94 \\
\hline Gadgadvani & & 5.88 \\
\hline
\end{tabular}

Table 2: objective criteria:

BMI Found In 17 Patients of Sthaulya (Obesity)

\begin{tabular}{|c|c|c|}
\hline BMI $\left(\mathbf{k g} / \mathbf{m}^{\mathbf{2}}\right)$ & No. of Patients & $\%$ \\
\hline $\mathbf{2 5}-\mathbf{2 9 . 9}$ & 6 & 35.29 \\
\hline $\mathbf{3 0}-\mathbf{3 4 . 9}$ & 7 & 41.18 \\
\hline $\mathbf{3 5}-\mathbf{4 0}$ & 4 & 23.53 \\
\hline
\end{tabular}

Waist Circumference Found In 3 Males of Sthaulya (Obesity)

\begin{tabular}{|c|c|c|}
\hline $\begin{array}{c}\text { Waist } \\
\text { circumference } \\
\text { (in cm) }\end{array}$ & $\begin{array}{c}\text { No. of } \\
\text { Patients }\end{array}$ & \% \\
\hline$\leq \mathbf{1 0 2}$ & 2 & 66.67 \\
\hline$>\mathbf{1 0 2}$ & 1 & 33.33 \\
\hline
\end{tabular}

Waist Circumference Found In 14 Females of Sthaulya (Obesity)

\begin{tabular}{|c|c|c|}
\hline $\begin{array}{c}\text { Waist } \\
\text { circumference } \\
\text { (In cm) }\end{array}$ & No. of Patients & $\%$ \\
\hline$>\mathbf{8 8}$ & 11 & 78.57 \\
\hline$\leq \mathbf{8 8}$ & 3 & 21.43 \\
\hline
\end{tabular}

Waist To Hip Ratio Observed In 3 Male of Sthaulya (Obesity)

\begin{tabular}{|c|c|c|}
\hline $\begin{array}{c}\text { Waist } \\
\text { circumference }\end{array}$ & $\begin{array}{c}\text { No. of } \\
\text { Patients }\end{array}$ & \% \\
\hline$>\mathbf{0 . 9}$ & 3 & 100 \\
\hline$\leq \mathbf{0 . 9}$ & 0 & 00 \\
\hline
\end{tabular}

Waist To Hip Ratio Observed In 14 Female of Sthaulya (Obesity)

\begin{tabular}{|c|c|c|}
\hline $\begin{array}{c}\text { Waist } \\
\text { circumference }\end{array}$ & No. of Patients & $\%$ \\
\hline$>\mathbf{0 . 8 5}$ & 10 & 71.43 \\
\hline$\leq \mathbf{0 . 8 5}$ & 4 & 28.57 \\
\hline
\end{tabular}

\section{Effect of Bilvadi Panchmool Ghanvati}

\section{Subjective criteria:}

- Improvement in symptoms were Alasya/ Utsahahani (laziness or lack of enthusiasm) $45.45 \%$, Kshudra Shwasa (dyspnoea on exertion) by $63.64 \%$ and Daurblyata-Alpa Vyayam (weakness) 48.28\% which were highly significant.

- Improvement in symptoms like Chala Sphika (Visible Movement In Hip) 20.51\%, Chala Udara (Visible Movement In Abdomen) 26.19\%, Chala Stana(Visible Movement In Breast) 19.35\%, Nidradhikya (excess sleep) 47.83\%, Swedadhikya (excess sweating) 44.83\%, Daurgaandhya (body odour) by $42.11 \%$, Ati Pipasa (excess thirst) 52\% and Ati Kshudha (excess hunger) 45\% which were significant.

- Improvements in symptoms like Alpa Vyavaya (Less Libido) 31.25\%, Anga Shaithilya (flabbiness in the body) $33.33 \%$ and Gadgadvani (Indistinct speech) $0.00 \%$ which were no significant. 
Table 3: Effect of Therapy on subjective criteria

\begin{tabular}{|l|c|c|c|c|c|c|c|}
\hline Symptoms & $\begin{array}{c}\text { Mean } \\
\text { B.T. }\end{array}$ & $\begin{array}{c}\text { Mean } \\
\text { A.T }\end{array}$ & $\begin{array}{c}\text { Mean } \\
\text { Diff. }\end{array}$ & $\begin{array}{c}\text { \%o } \\
\text { Change }\end{array}$ & 'W' & 'N' & 'P' \\
\hline Chala Sphika & 3 & 2.38 & 0.62 & $20.51 \downarrow$ & 36.00 & 13 & $<0.01$ \\
\hline Chala Udara & 2.8 & 2.07 & 0.73 & $26.19 \downarrow$ & 55.00 & 15 & $<0.01$ \\
\hline Chala Stana & 2.58 & 2.08 & 0.5 & $19.35 \downarrow$ & 21.00 & 12 & $<0.05$ \\
\hline Alasya/Utsahahani & 2.54 & 1.38 & 1.16 & $45.45 \downarrow$ & 91.00 & 13 & $<0.001$ \\
\hline Kshudra Shwasa & 2.75 & 1 & 1.75 & $63.64 \downarrow$ & 78.00 & 12 & $<0.001$ \\
\hline $\begin{array}{l}\text { Daurbalyata-Alpa } \\
\text { Vyayama }\end{array}$ & 2.42 & 1.25 & 1.17 & $48.28 \downarrow$ & 78.00 & 6 & $<0.001$ \\
\hline Nidradhikya & 2.09 & 1.09 & 1 & $47.83 \downarrow$ & 45.00 & 11 & $<0.01$ \\
\hline Swedadhikya & 2.42 & 1.33 & 1.09 & $44.83 \downarrow$ & 55.00 & 12 & $<0.01$ \\
\hline Daurgaandhya & 1.9 & 1.1 & 0.8 & $42.11 \downarrow$ & 36.00 & 10 & $<0.01$ \\
\hline Atipipasa & 2.08 & 1 & 1.08 & $52 \downarrow$ & 55.00 & 12 & $<0.01$ \\
\hline Atikshudha & 1.67 & 0.92 & 0.75 & $45 \downarrow$ & 36.00 & 12 & $<0.01$ \\
\hline Alpa Vyavaya & 2.28 & 1.57 & 0.71 & $31.25 \downarrow$ & 15.00 & 7 & $>0.05$ \\
\hline Anga Shaithilya & 1.88 & 1.25 & 0.63 & $33.33 \downarrow$ & 15.00 & 8 & $>0.05$ \\
\hline Gadgadvani & 1 & 1 & 0 & 0 & 0.00 & 1 & $>0.05$ \\
\hline Sandhi Shoola & 2.8 & 1.4 & 1.4 & $50 \downarrow$ & 15 & 5 & $>0.05$ \\
\hline
\end{tabular}

Objective criteria:

- There was a highly significant decrease of $2.87 \%$ and $2.85 \%$ found in Weight and BMI respectively.

- There was a highly significant decrease in organ measurement of $2.83 \%$ and $1.48 \%$ was found in Waist and Chest respectively.

- There was a statistically significant reduction in organ measurement was reported in Hip by $1.59 \%$ and $1.39 \%$ in Mid arm, while Abdomen, Mid thigh, Mid calf also reduced significantly by $1.74 \%, 1.59 \%$ and $1.04 \%$ respectively.

- Insignificant reduction of $1.04 \%$ and $1.30 \%$ were found in Neck and Mid forearm respectively.

- There was a significant decrease in W/H Ratio of $1.52 \%$.

- There was a significant decrease in various skin fold thickness i.e. Biceps by $6.33 \%$, Triceps $7.07 \%$, Abdomen $6.57 \%$, Supra iliac $10.79 \%$.

Table 4: Effect of Therapy on Weight and BMI of Patients of Sthaulya (Obesity)

\begin{tabular}{|c|c|c|c|c|c|c|c|c|}
\hline \multirow{2}{*}{$\begin{array}{c}\text { Parameter } \\
(\mathbf{n}=\mathbf{1 5})\end{array}$} & \multicolumn{2}{|c|}{ Mean } & $\begin{array}{c}\text { Mean } \\
\text { Differ- } \\
\text { ence }\end{array}$ & $\begin{array}{c}\text { \%.T } \\
\text { change }\end{array}$ & S.D. \pm & S.E. \pm & 't ' & P \\
\hline Weight(kg) & 78.07 & 75.83 & 2.24 & $2.87 \downarrow$ & 0.77 & 0.20 & 11.34 & $<0.001$ \\
\hline BMI $\left(\mathbf{k g} / \mathbf{m}^{\mathbf{2}}\right)$ & 32.08 & 31.17 & 0.91 & $2.85 \downarrow$ & 0.32 & 0.08 & 11.12 & $<0.001$ \\
\hline
\end{tabular}

$\uparrow$-Increase, $\downarrow$ - Decrease

Table 5: Effect of Therapy on Body Organ Measurement of Patients of Sthaulya (Obesity)

\begin{tabular}{|c|c|c|c|c|c|c|c|c|}
\hline \multirow{2}{*}{$\begin{array}{c}\text { Parameter } \\
(\mathrm{n}=15) \\
(\text { in cm) }\end{array}$} & \multicolumn{2}{|c|}{ Mean } & \multirow{2}{*}{$\begin{array}{l}\text { Mean } \\
\text { Differ- } \\
\text { ence }\end{array}$} & \multirow{2}{*}{$\begin{array}{c}\% \\
\text { change }\end{array}$} & \multirow{2}{*}{ S.D. \pm} & \multirow{2}{*}{ S.E.土 } & \multirow{2}{*}{${ }^{6} \mathrm{t}$} & \multirow{2}{*}{$\mathbf{P}$} \\
\hline & B.T. & A.T. & & & & & & \\
\hline Neck & 35.78 & 35.4 & 0.38 & $\overline{1.04 \downarrow}$ & 0.726 & 0.187 & 1.81 & $>0.05$ \\
\hline Mid Arm & 33.6 & 33.13 & 0.47 & $1.39 \downarrow$ & 0.481 & 0.124 & 3.76 & $<0.01$ \\
\hline Mid Forearm & 25.63 & 25.3 & 0.33 & $1.30 \downarrow$ & 0.772 & 0.199 & 1.67 & $>0.05$ \\
\hline Chest & 101.57 & 100.07 & 1.5 & $1.48 \downarrow$ & 1.32 & 0.34 & 4.39 & $<0.001$ \\
\hline Abdomen & 99.7 & 97.97 & 1.73 & $1.74 \downarrow$ & 2.74 & 0.709 & 2.44 & $<0.05$ \\
\hline Waist & 99.03 & 99.23 & 2.8 & $2.83 \downarrow$ & 1.771 & 0.457 & 6.12 & $<0.001$ \\
\hline Hip & 113.33 & 111.53 & 1.8 & $1.59 \downarrow$ & 1.88 & 0.487 & 3.69 & $<0.01$ \\
\hline Mid thigh & 56.77 & 55.87 & 0.9 & $1.59 \downarrow$ & 1.478 & 0.382 & 2.35 & $<0.05$ \\
\hline Mid Calf & 38.47 & 38.07 & 0.4 & $1.04 \downarrow$ & 0.604 & 0.156 & 2.56 & $<0.05$ \\
\hline W/H Ratio & 0.876 & 0.863 & 0.013 & $1.52 \downarrow$ & 0.019 & 0.004 & 2.69 & $<0.05$ \\
\hline
\end{tabular}

$\uparrow$-Increase, $\downarrow$ - Decrease

W/H RATIO: There was a decrease in $\mathrm{W} / \mathrm{H}$ Ratio of $1.52 \%$, which was statistically significant $(\mathrm{p}<0.05)$. 
Vyas Jatin M et.al., A Clinical study of Bilvadi panchamool ghanvati in the management of Sthaulya (Obesity)

Table 6: Effect of Therapy on Skin Fold Thickness of Patients of Sthaulya (Obesity)

\begin{tabular}{|c|c|c|c|c|c|c|c|c|}
\hline $\begin{array}{c}\text { Skin Fold Thick- } \\
\text { ness(in mm) }\end{array}$ & $\begin{array}{c}\text { BT } \\
\text { Mean }\end{array}$ & $\begin{array}{c}\text { AT } \\
\text { Mean }\end{array}$ & $\begin{array}{c}\text { Mean } \\
\text { Diff. }\end{array}$ & $\begin{array}{c}\text { \%o } \\
\text { change }\end{array}$ & S.D. \pm & S.E. \pm & 't & P \\
\hline Biceps & 16.44 & 15.4 & 1.04 & $6.33 \downarrow$ & 1.17 & 0.30 & 3.45 & $<0.01$ \\
\hline Triceps & 18.09 & 16.81 & 1.28 & $7.07 \downarrow$ & 1.36 & 0.35 & 3.64 & $<0.01$ \\
\hline Abdomen & 24.06 & 22.48 & 1.58 & $6.57 \downarrow$ & 1.50 & 0.39 & 4.08 & $<0.01$ \\
\hline Supra iliac & 26.20 & 23.38 & 2.82 & $10.79 \downarrow$ & 2.94 & 0.76 & 3.73 & $<0.01$ \\
\hline
\end{tabular}

$\uparrow$-Increase, $\downarrow$ - Decrease, $*_{n}=15$

\section{Laboratory values:}

There was a decrease of $7.46 \%, 2.52 \%$ and $1.63 \%$ found in WBC Total, S.Cholesterol and FBS respectively, while there was an increase by $1.45 \%$ and $0.93 \%$ were found in $\mathrm{RBC}$ and $\mathrm{Hb}(\%)$ respectively. All these changes were statistically insignificant.

\section{Overall effect of Therapy:}

In Bilvadi Panchmool Ghanvati group total 15 patients completed the treatment of which maximum i.e. 6 patients $(40 \%)$ reported improved followed by 3 patients $(20 \%)$ found in each moderately and mild improved. $(6.67 \%)$ was markedly improved while 2 patients $(13.33 \%)$ remained unchanged.

Table 7: overall effect of therapy

\begin{tabular}{|c|c|c|}
\hline Improvement & No. of Patients & \% \\
\hline Complete remission & 0 & 0 \\
\hline Markedly improved & 1 & 6.67 \\
\hline Moderately improved & 3 & 20 \\
\hline Improved & 6 & 40 \\
\hline Mildly improved & 3 & 20 \\
\hline Unchanged & 2 & 13.33 \\
\hline
\end{tabular}

Chart: 1

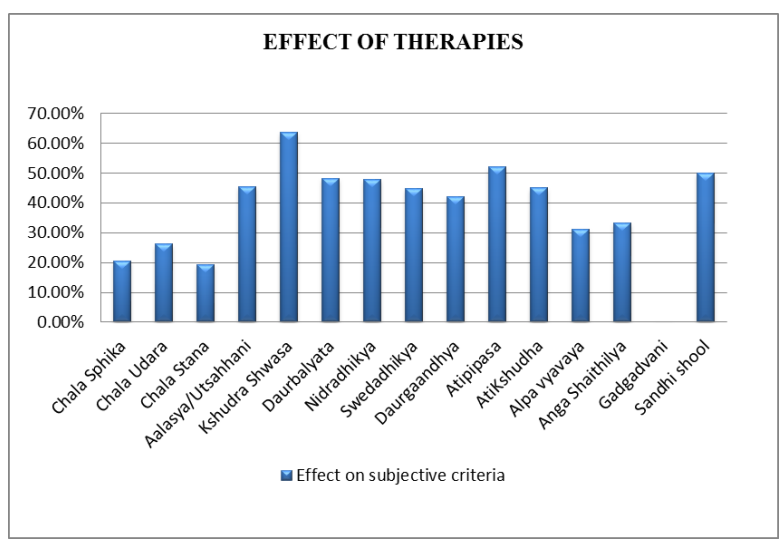

Chart: 2

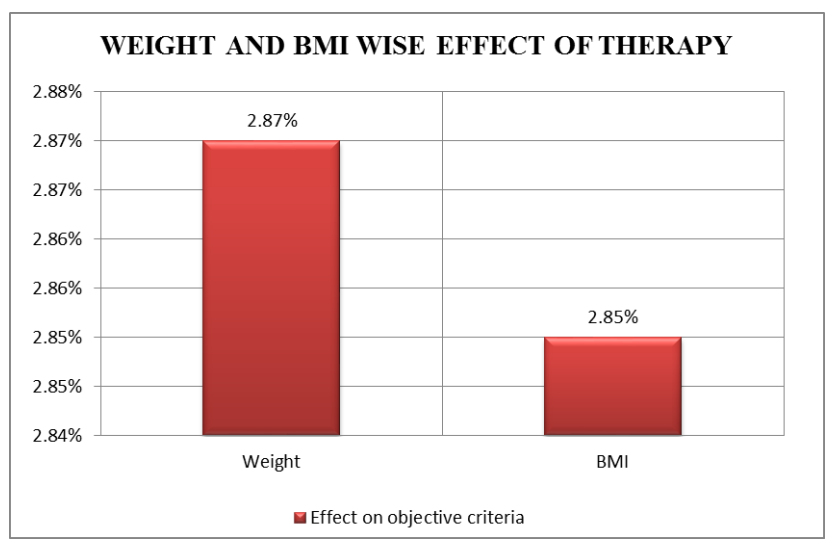

Chart 3:

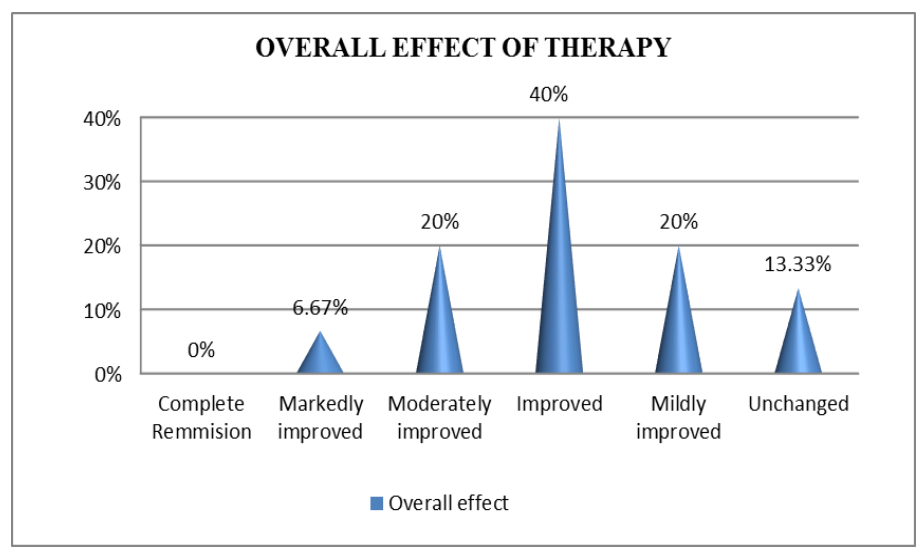




\section{Discussion}

Aacharya Charaka said that as wholesome diet is needed for maintenance of body so is the sleep. Obesity and leanness are particularly caused by sleep and diet (6). Therefore we discuss causative factors as:

\section{Aharaj Nidana (Dietary Factors)}

In Aharaja Nidanas, Madhura Ahara Sevana was found in Maximum i.e. $81.82 \%$ patients followed by Guru Ahara Sevana in 76.47\%, Atisnigdha Ahara and Navanna in $70.59 \%$ in each, Atibhojanat in $58.82 \%$ Dadhi Sevana in $41.17 \%$.

\section{Viharaja Nidana}

In Viharaja Nidanas, Maximum i.e. $76.47 \%$ patients were found to have Avyayama (lack of excersice) as a Nidana followed by $58.82 \%$ of the patients having Divaswapa.

\section{Mansika Nidana (Psychological factors)}

Among psychological factors Nityapraharsh (always jolly nature) was found predominant in $64.71 \%$ followed by Achintana (thinking less) in $47.06 \%$ patients and Atichinta (stress) in $35.29 \%$ patients. Mansika nidana may act in two ways, mental tendency like Nityaharsha and Achintana leads to mental satisfaction and Sthairya, which may to increase Manda, Stimita, Sandra and Guru Guna of Kapha. While Atichintana and chintita (stress and anxiety) helps to diminish the function of Rasa Vaha Srotas (7) and also decreases normal digestive power(8) which ultimately decreases Jatharagni and Medodhatvagni, which causes Ajirna hence leading to Ama formation thus deteriorating the pathogenesis further

Other factors

Beejadosha (positive parental history) was reported in $35.29 \%$ of patients.

Mode of action of Bilvadi Panchmool Ghanvati

In the disease Sthaulya, Tikshnagni occurs. Here, Jatharagni is found in excessive condition whereas Medodhatvagni is found in Manda condition. It is due to Avarana of Vayu in Kostha. So person indulges in more food, which produce excessive Meda and this vitiated cycle go on. This cycle is wrecked (Samprapti Vighatana) by Kashaya - Tikta Rasa and Ushna-Virya Pradhana drugs.

All the five drugs of Bilvadi Panchmool Ghanvati possess Kashaya and Tikta Rasa as Pradhana Rasa. Kashaya Rasa has Samshamana, Shoshana, Shelshma Rakta Pitta Prashamana, Kledashoshana, Ruksha, Sheeta and Laghu.(9)Tikta Rasa by its Laghu (light), Ruksha (dry) properties; helps in Kaphashamana.(10)

Brihat Panchamoola is having Ushna Virya which helps to pacify Vriddha Vata. It is having Madhura Rasa as Anurasa which alleviates Pitta.

Adverse Drug Reaction

No any adverse drug reaction or side effects were observed during or after completion of treatment. So the treatment which is employed in the study is safe.

\section{Conclusion}

By the assessment of subjective and objective criteria, significant difference was found in before and after treatment. As a whole, it can be concluded that Bilvadi Panchmool Ghanvati has shown very good effect in the patients, which is also proved statistically. Bilvadi Panchmool Ghanvati showed result by its virtues of Vata-Kaphanashana and Deepana which also justifies Kapha-Vata dominancy of Sthaulya. The fact substantiate hypothesis that use of Vata-Kaphanashana drug is as useful as the drug prepared with Guggulu in Sthaulya.

Bilvadi Panchmool Ghanvati has significant effect in Sthaulya.

\section{References}

1. Braunwald, Kasper et.al.Harisson's -Principles of Internal Medicine, New York: MCGraw Hill, 17 ${ }^{\text {th }}$ Edition, 2008.

2. http://www.who.int/mediacentre/factsheets/fs311/ en/, retrieved on $1 / 7 / 13$

3. http://www.who.int/en/, retrieved on 1/9/12

4. Acharya Agnivesha, Vaidya Jadavaji Trikamji Acarya,Charaka Samhita - Ayurveda Dipika Commentary of Chakrapanidatta, Varanasi Chaukhamba Sanskrit Sansthana, Edition reprint 2011,Sutra sthan.23/6.

5. Acharya Agnivesha, Vaidya Jadavaji Trikamji Acarya,Charaka Samhita - Ayurveda Dipika Commentary of Chakrapanidatta, Varanasi Chaukhamba Sanskrit Sansthana, Edition reprint 2011,Sutra sthan.21/24.

6. Acharya Agnivesha, Vaidya Jadavaji Trikamji Acarya,Charaka Samhita - Ayurveda Dipika Commentary of Chakrapanidatta, Varanasi Chaukhamba Sanskrit Sansthana, Edition reprint 2011,Sutra sthan.21/51.

7. Acharya Agnivesha, Vaidya Jadavaji Trikamji Acarya,Charaka Samhita - Ayurveda Dipika Commentary of Chakrapanidatta, Varanasi Chaukhamba Sanskrit Sansthana, Edition reprint 2011, Viman sthan 5/13.

8. Acharya Agnivesha, Vaidya Jadavaji Trikamji Acarya,Charaka Samhita - Ayurveda Dipika Commentary of Chakrapanidatta, Varanasi Chaukhamba Sanskrit Sansthana, Edition reprint 2011, Viman sthan 1/24-25.

9. Acharya Agnivesha, Vaidya Jadavaji Trikamji Acarya,Charaka Samhita - Ayurveda Dipika Commentary of Chakrapanidatta, Varanasi Chaukhamba Sanskrit Sansthana, Edition reprint 2011,Sutra sthan. 26/42[6].

10. Acharya Agnivesha, Vaidya Jadavaji Trikamji Acarya,Charaka Samhita - Ayurveda Dipika Commentary of Chakrapanidatta, Varanasi Chaukhamba Sanskrit Sansthana, Edition reprint 2011,Sutra sthan. 26/42[5]. 